\title{
The Influence of Good Corporate Governance and Corporate Social Responsibility on the Value of Banking Companies Listed on the Indonesia Stock Exchange
}

\author{
Anhar Firdaus $^{1 *}$, Fazli Syam BZ ${ }^{2}$, Yossi Diantimala ${ }^{3}$, Syawal Harianto ${ }^{4}$ \\ ${ }^{1,4}$ Jurusan Tata Niaga, Politeknik Negeri Lhokseumawe,Lhokseumawe, Indonesia \\ ${ }^{2,3}$ Fakultas Ekonomi dan Bisnis, Universitas Syiah Kuala,Banda Aceh, Indonesia \\ *Email Corespondent : anhar.firdaus@pnl.ac.id
}

\begin{abstract}
This reasearch purpose to examine the Good Corporate Governance and Corporate Social Responsibility both simultaneously and partially to Firm Value on Indonesian Banks in the period of 2011-2015. The methode of analysis used in this reasearch is path analysis for hypotesting test and SPSS for classic assumption test. The type used in this reasearch is study are causality, using purposive sampling method and unbalanced panel data. The object of this reasearch consists of 11 banks with 38 observational data. The results show that (1) Good Corporate Governance and Corporate Social Responsibility simultaneously no influence to firm value; (2) Good Corporate Governance has no influence to firm value; (3) Corporate Social Responsibility has no influence to firm value.
\end{abstract}

Keywords : Good Corporate Governance, Corporate Social Responsibility, firm value

\begin{abstract}
Abstrak: Penelitian ini bertujuan untuk menguji pengaruh Good Corporate Governance dan Corporate Social Responsibility baik secara bersama-sama maupun parsial terhadap nilai perusahaan perbankan yang terdaftar di Bursa Efek Indonesia periode 2011-2015. Metode analisis data pada penelitian ini menggunakan analisa jalur untuk pengujian hipotesis, sedangkan SPSS digunakan untuk uji asumsi klasik. Jenis penelitian yang digunakan dalam penelitian ini bersifat kausalitas dengan menggunakan metode purposive sampling dan unbalanced panel data. Objek penelitian berjumlah 11 bank dengan 38 data pengamatan.. Hasil penelitian ini menunjukkan bahwa: (1) Good Corporate Governance dan Corporate Social Responsibility secara bersama-sama tidak berpengaruh terhadap nilai perusahaan; (5) Good Corporate Governance tidak berpengaruh terhadap nilai perusahaan; (6) Corporate Social Responsibility tidak berpengaruh terhadap nilai perusahaan pada perusahaan.
\end{abstract}

Keywords : Good Corporate Governance, Corporate Social Responsibility, kinerja keuangan, nilai perusahaan 


\section{INTRODUCTION}

The establishment of a company has the main goal, namely to get the maximum profit by making a profit and to maximize the value of the company. In the current era of globalization, company management is appointed as an extension of the owner of capital to carry out and manage business activities so that the company is able to survive (sustainability) in facing all competitive situations and economic conditions as it is today. The increase in the value of the company can be influenced by the results of the company's performance. Financial performance is one aspect of the company's assessment based on published financial reports. Financial performance information will influence decision-making behavior. Companies will disclose information if the information will increase the value of the company.

Information presented other than financial information is non-financial information. In the midst of the rapid development of information and high accountability, the company is also expected to be able to provide non-financial information. One of the information can be in the form of GCG (Good Corporate Governance) reports and CSR (Corporate Social Responsibility) reports. The process of maximizing the value of the company will lead to a conflict which is often called the agency problem. The conflict arises because of differences in interests between managers and shareholders, this happens because managers prioritize personal interests, otherwise shareholders will not increase costs for the company so that a decrease in company profits / performance occurs and affects the share price owned. the impact on firm value decreases (Jensen and Meckling, 1976). The concept of GCG arises in order to identify potential incidents due to agency problems and ensure that management acts in the best interests of the company.

POJK (Peraturan Otoritas Jasa Keuangan) No. 55/POJK.03/2016 require banks to carry out their business activities based on the principles of good governance in order to improve bank performance, protect the interests of stakeholders, and improve compliance with laws and regulations and generally accepted ethical values (code of conduct). in the banking industry. Learn from experiences during the global financial crisis in 1998 and 2008, where the implementation of weak corporate governance practices has been identified as one of the main causes of the global financial crisis (Zhuang, 2000:1). In this regard, improving the implementation of corporate governance practices is very important and a top priority in Indonesia.

Table 1 shows the results of the Corporate Governance Watch survey issued by CLSA Asia-Pacific Markets.
Table 1 Corporate Governance Watch

\begin{tabular}{lcccccc}
\hline \multirow{2}{*}{ Country } & \multicolumn{7}{c}{ Years } \\
\cline { 2 - 7 } & $\mathbf{2 0 0 5}$ & $\mathbf{2 0 0 7}$ & $\mathbf{2 0 1 0}$ & $\mathbf{2 0 1 2}$ & $\mathbf{2 0 1 4}$ & $\mathbf{2 0 1 6}$ \\
\hline Australia & - & - & - & - & - & 78 \\
\hline Singapore & 70 & 65 & 67 & 69 & 64 & 67 \\
\hline Hong Kong & 69 & 67 & 65 & 66 & 65 & 65 \\
\hline Japan & - & 52 & 57 & 55 & 60 & 63 \\
\hline Taiwan & 52 & 54 & 55 & 53 & 56 & 60 \\
\hline Thailand & 50 & 47 & 55 & 58 & 58 & 58 \\
\hline Malaysia & 56 & 49 & 52 & 55 & 58 & 56 \\
\hline India & 61 & 56 & 49 & 51 & 54 & 55 \\
\hline Korea & 50 & 49 & 45 & 49 & 49 & 52 \\
\hline China & 44 & 45 & 49 & 45 & 45 & 43 \\
\hline Philippines & 46 & 41 & 37 & 41 & 40 & 38 \\
\hline Indonesia & 37 & 37 & 40 & 37 & 39 & 36 \\
\hline \multicolumn{1}{c}{ Source: CLSA AsiaPafic }
\end{tabular}

Source: CLSA Asia-Pacific Markets (reworked 2021)

The survey results in Table 1 show that of the 12 Asian markets, the lowest position is occupied by Indonesia. This means that the practice of implementing corporate governance in Indonesia is still very low/weak (CLSA, 2016:14).

Another non-financial information that is also a regulatory and ethical driver is the CSR report. The CSR report is one of the reports that must be included in the company's annual report as regulated in the Law of the Republic of Indonesia no. 40 of 2007 concerning social and environmental responsibility which requires companies whose business activities are in the field and/or related to natural resources to carry out social and environmental responsibilities. With a strong legal basis, companies are required to report CSR activities.

This research is a replication and development (expand replicant) of previous research (Dewi and Suardana, 2015). The different is:

1) This study uses a sample of companies that are included in the category of Indonesia's Most Trusted Companies Based on Corporate Governance Perception Index in Indonesia.

2) This research differs from previous research by adding CSR.

3) This study uses an observation period of 20112015.

Through this research, the writer wants to see the effect of Good Corporate Governance and Corporate Social Responsibility on the Value of Banking Companies Listed on the Indonesia Stock Exchange for the period 2011-2015. Through the results of this study, it is hoped that it can be used as a reference for management so that companies no longer make GCG and CSR disclosures a burden, but should make this 
non-financial information one of the tools in increasing company value.

This research is also useful for investors because by knowing the relationship between the variables studied, investors can choose companies that will become a place to invest by paying attention to factors, both financial and non-financial information.

\section{LITERATURE REVIEW}

\section{Agency Theory}

Agency theory developed by Michel Johnson views company management as "agents" for shareholders, who will act with full awareness for their own interests, not as wise and wise and fair parties to shareholders. There is a separation of ownership (ownership structure) between owners and managers in a company. The emergence of relationship problems between agents and principals (agency problems) occurs when managers do not always act in the interests of shareholders. The concept of GCG arises in order to minimize the potential for fraud due to agency problems and to ensure that management acts in the best interests of the company.

\section{Stewardship Theory}

According to Chin and Shaw (2000 and 2003), stewardship theory is built on philosophical assumptions about human nature, namely that humans are essentially trustworthy, able to act responsibly, have integrity and honesty with others. This is implied in the fiduciary relationship that the shareholders want. In this theory, management is seen as trustworthy to act in the best possible way for the interests of stakeholders and the public interest.

GCG is a system that regulates and controls the company in order to create added value for all stakeholders. There are two things that are emphasized in this concept, namely: (1) the importance of the right of shareholders to obtain correct and timely information and (2) the company's obligation to make accurate, timely and transparent disclosures of all performance information. company, ownership, and stakeholders.

\section{Stakeholder Theory}

According to Ghazali and Chariri (2007:409), Stakeholder Theory is a theory which states that a company is not an entity that only operates for its own sake, but must provide benefits to all its stakeholders (shareholders, creditors, consumers, suppliers, government, society, analysts, and other parties). This stakeholder group becomes the consideration for the company's management in disclosing or not an information in the company's report.

Ullmann and Roberts RW put forward stakeholder theory with the assumption that the existence of the company is determined by the stakeholders. The company will seek justification from stakeholders in running the company's operations. The stronger the stakeholder position, the greater the tendency of the company to adapt itself to the wishes of its stakeholders which in the end management will try to improve information that can have an impact on the company..

\section{Legitimacy Theory}

Legitimacy theory is built on the principle that the company has a contract with the community to carry out its business activities based on the value of justice, and how the company responds to various interest groups around the company. One of the reports that support the legitimacy of the company is in the form of CSR disclosure in the annual report which is expected to be able to help companies to gain social legitimacy and maximize the value of the company in the long term, as well as a balance between the company's value system and the value of the community in the company.

\section{The value of the company}

Company value according to Martono and Harjito (2006:13) for companies that have gone public is the value of the company which is reflected in the market value of its shares, while for companies that have not gone public it is defined as the value that occurs when the company is sold. In line with the statement Husnan (2008: 5) means that the value of companies that have gone public is reflected in the value of shares in the capital market, while for those who have not gone public, company value is a number of costs that prospective buyers are willing to pay if the company is sold. . The method of calculating firm value refers to Smithers and Wright (2007:37) using Tobin's Q developed by Klapper and Love.

\section{Good Corporate Governance}

Governance according to ISO (International Standard) FDIS 26000:2010 is defined as a system by which an organization makes and implements decisions in pursuit of its objectives. The essence of corporate governance is the improvement of the company's performance through supervision or monitoring of management performance and the existence of management accountability to other stakeholders, based on the applicable rules and regulations framework.

In the current era of globalization and information, information is an important commodity needed by society. When it comes to financial statements, the full disclosure of information is to communicate the financial position by not hiding information (Belkaoui, 2000: 219). Disclosure of GCG (Good Corporate Governance) information is a form of comprehensive disclosure.

The World Bank defines the meaning of good corporate governance as

"...a combination of laws, regulations and practices undertaken by the private sector on a voluntary basis 
The Influence of Good Corporate Governance and Corporate Social Responsibility on the Value of Banking Companies Listed on the Indonesia Stock Exchange

Anhar Firdaus, Fazli Syam BZ, Yossi Diantimala, Syawal Harianto that enables companies to attract financial capital and labor, perform efficiently, and thereby sustainably generate long-term economic value. for its shareholders, while at the same time paying attention to the interests of stakeholders and society as a whole" (Maassen, 2000:1).

In this study, GCG is measured by the CGPI (Corporate Governance Perception Index) index. Suprayitno (2009:5) states that the CGPI organized by the IICG (Indonesian Institute for Corporate Governance) is a research and rating program for the implementation of GCG in companies in Indonesia, followed by public companies (issuers), BUMN, banks and other private companies. This program is designed to trigger companies to improve the quality of the implementation of the $\mathrm{CG}$ concept through continuous improvement by conducting evaluations and conducting comparative studies (benchmarking).

\section{Corporate Social Responsibility}

The concept of CSR (Corporate Social Responsibility) or better known as social and environmental responsibility in Indonesia was first proposed by Howard R. Bowen in 1953. The implementation of CSR in companies has become increasingly important with the emergence of the concept of sustainable development by WBCSD (The World Business Council). for Sustainable Development) which continues to develop. WBCSD (1998:3) mentions CSR "is the continuing commitment by business to behave ethically and contribute to economic development while improving the quality of life of the workforce and their families as well as of the local community and society at large". In this study, CSR is calculated referring to the Sustainability Reporting Guidelines published by GRI (Global Reporting Initiative) by observing whether there is an item of information specified in the report presented..

The Influence of GCG and CSR on Company Value

The purpose of establishing a company is to make a profit. Profits generated from the company's operational activities will reflect the company's performance which in turn will affect the value of the company in the eyes of investors. In addition to the push for obligations that have been regulated by the regulator, the company will disclose information that can increase the value of the company. Disclosure of GCG and CSR information is expected to be able to provide positive value for the company, both on financial and non-financial information.

The results of this study explain that there is a significant relationship between GCG and CSR with firm value, so the hypothesis proposed in this study is:

Ha1 : GCG and CSR together affect the value of the company.

Ha2 : GCG has an effect on firm value.

$\mathrm{Ha} 3$ : CSR has an effect on firm value.
Based on the relationship between these variables, the conceptual framework drawing is as follows:

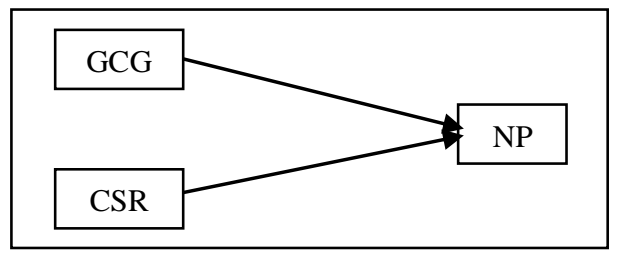

\section{Figure 1 Schematic Framework of Thinking}

\section{RESEARCH METHODS}

\section{Population and Sample}

According to Sugiyono (2009:59), population is a generalization area consisting of objects/subjects that have certain quantities and characteristics determined by researchers to be studied and then drawn conclusions. The population of companies used in this study are banking companies listed on the Indonesia Stock Exchange.

This study uses a sample. The sample selection in this study was carried out by purposive sampling method, which is a sampling method adapted to certain criteria (Sekaran, 2006:136). The criteria for the companies that are sampled in this study are as follows:

1) Companies listed on the Indonesia Stock Exchange during the study period from 2011-2015.

2) Companies that have a CGPI Index value during the research period from 2011-2015.

3) Banking companies that have a CGPI Index value during the research period from 2011-2015.

Based on these criteria, 11 banking companies became the research sample with a total of 38 observational data during the 2011-2015 period.

Table 2 Operationalization of Data Variables

\begin{tabular}{ccc}
$\begin{array}{c}\text { Variable } \\
\text { Name }\end{array}$ & \multicolumn{1}{c}{ Measurement } & Scale \\
$\begin{array}{c}\text { Nilai } \\
\text { Perusahaan }\end{array}$ & \multicolumn{1}{c}{$\begin{array}{c}(\mathrm{EMV}+\mathrm{D}) \\
(\mathrm{EBV}+\mathrm{D})\end{array}$} & Ratio \\
\hline GCG & \multicolumn{1}{c}{ CGPI Indeks } & Ratio \\
\hline CSRDI $=\frac{\sum \mathrm{Xi}}{\mathrm{N}}$ & \\
CSR & $\begin{array}{l}\text { Score } 0 \quad: \text { If the company does not } \\
\text { disclose CSR items in the } \\
\text { company's financial statements. } \\
\text { Score 1 : If the company discloses } \\
\text { CSR items in the company's } \\
\text { financial statements. }\end{array}$ & Ratio \\
\hline
\end{tabular}

Source: Processed Data (2021)

Data analysis method

The analytical method used in this study is path analysis which is used to measure the relationship between the dependent variable (firm value) and the independent variable (GCG and CSR) (Gujarati, 2003). Before conducting the 
The Influence of Good Corporate Governance and Corporate Social Responsibility on the Value of Banking Companies Listed on the Indonesia Stock Exchange

Anhar Firdaus, Fazli Syam BZ, Yossi Diantimala, Syawal Harianto analysis, descriptive statistical tests and classical assumption tests were carried out. Descriptive statistical analysis was conducted to determine the dispersion and distribution of the data. While the classical assumption test is carried out to test the feasibility of the regression model which will then be used to test the research hypothesis. The structural model obtained is formulated with the following equation: $\mathrm{Y}=$ $\rho 1 \mathrm{X} 1+\rho 2 \mathrm{X} 2+\mathrm{e} 1$

$$
\begin{aligned}
& \text { Keterangan: } \\
& \begin{array}{ll}
\mathrm{X} 1 & =\mathrm{GCG} \\
\mathrm{X} 2 & =\mathrm{CSR} \\
\mathrm{Y} & =\text { The value of the company } \\
\rho 1, \rho 2 & =\text { Path Coefficient } \\
\mathrm{e} 1 & =\text { Error Terms }
\end{array}
\end{aligned}
$$

\section{RESULT AND DISCUSSION}

\section{Descriptive statistics}

Based on the test results with a total of 38 observation data, the following results were obtained:

\begin{tabular}{lrrrrr}
\hline \multicolumn{5}{c}{ Tabel 3 Descriptive Statistics } \\
& N & Minimum & Maximum & Mean & $\begin{array}{c}\text { Std. } \\
\text { Deviation }\end{array}$ \\
\hline GCG & 38 & 77,80 & 93,29 & 86,2074 & 3,61119 \\
CSR & 38 & 30,91 & 90,14 & 57,7768 & 16,06733 \\
NP & 38 &, 92 & 1,45 & 1,0945 &, 12459 \\
Valid N & 38 & & & & \\
(listwise) & & & & & \\
\hline
\end{tabular}

Sumber : Output SmartPLS ${ }^{\mathrm{TM}}$

Based on Table 3 shows that:

a. a. Firm value variable is measured by Tobin's Q ratio where the lowest value is 0.92 which is owned by J-Trust Bank, Tbk. (Bank Mutiara Tbk.) in 2011. The highest score of 1.45 was owned by Bank BCA in 2014. The average value was 1.0945, this means that when referring to Weston and Copeland (2008:245) General banking in Indonesia that already has a CGPI index for the 2011-2015 period has a good value in the eyes of investors where investment in assets generates profits that provide a higher value than investment spending.

b. b. The GCG variable has the lowest value of 77.80 which is owned by Bank Jabar Banten in 2011. The highest value is 93.29 which is owned by Bank Mandiri in 2015. The average value of the GCG variable is 86.20 , which means that in general, banks that have The CGPI index in Indonesia for the 20112015 period has received the title of very trusted (Indonesian Most Trusted Companies).

c. c. The CSR disclosure variable was $30.91 \%$ owned by Bank BCA in 2015. The highest value was obtained at $90.14 \%$ owned by Bank OCBC in 2011. The average value was $57.77 \%$ which means that the average company Banks that have a CGPI index in
Indonesia for the 2011-2015 period have disclosed 82-95 CSR disclosure items according to the GRI guidelines.

\section{Classic assumption test \\ Normality test}

Normality test aims to test whether in a regression model, the dependent variable, the independent variable, the moderating variable or all three have a normal distribution or not. A good regression model is the distribution of normal data or close to normal using a non-parametric statistical test One-Sample Kolmogorov-Smirno.

Table 4 Normality Statistic Test Results One-Sample Kolmogorov-Smirnov Test

\begin{tabular}{llr}
\hline & \multicolumn{2}{c}{$\begin{array}{c}\text { Unstandardized } \\
\text { Residual }\end{array}$} \\
\hline $\mathrm{N}$ & Mean & 38 \\
Normal Parameters ${ }^{\mathrm{a}, \mathrm{b}}$ &, 0000 \\
& Std. Deviation & 1,01891 \\
& Absolute &, 125 \\
Most Extreme Differences & Positive &, 125 \\
& Negative &,- 089 \\
Kolmogorov-Smirnov Z &, 773 \\
Asymp. Sig. (2-tailed) &, 589 \\
\hline a. Test distribution is Normal. & \\
b. Calculated from data. & \\
Sumber : Output SPSS &
\end{tabular}

The value of Kolmogorov-Smirnov for the dependent variable ROA is 0.773 with a significance level above 0.05 , which is 0.589 so that it can be concluded that the residual data is normally distributed.

Uji Multikolinieritas

The results of the multicollinearity test of GCG and CSR variables on firm value are shown in Table 5 that the VIF value of each variable is $1.318,1.170$, and 1.345. The tolerance value (TOL) obtained is close to 1 so it can be concluded that the regression model is free from multicollinearity between independent variables.

Table 5 Multicollinearity Statistical Test Results Coefficients $^{\mathrm{a}}$

\begin{tabular}{lrr}
\hline \multirow{2}{*}{ Model } & \multicolumn{2}{c}{ Collinearity Statistics } \\
\cline { 2 - 3 } & Tolerance & VIF \\
\hline (Constant) & & \\
1 GCG &, 759 & 1,318 \\
CSR &, 854 & 1,170 \\
\hline a. Dependent Variable: NP & \\
Source : Output SPSS &
\end{tabular}

\section{Hetoroscedasticity Test}

Heteroscedasticity is an indication that the variance between residuals is not homogeneous which results in the estimated value obtained is no longer efficient. One way that can be used to detect the presence or absence of heteroscedasticity can be done by looking at the scatterplot graph. The results of the heteroscedasticity 
test for the GCG and CSR variables on firm value can be seen in Figure 2.

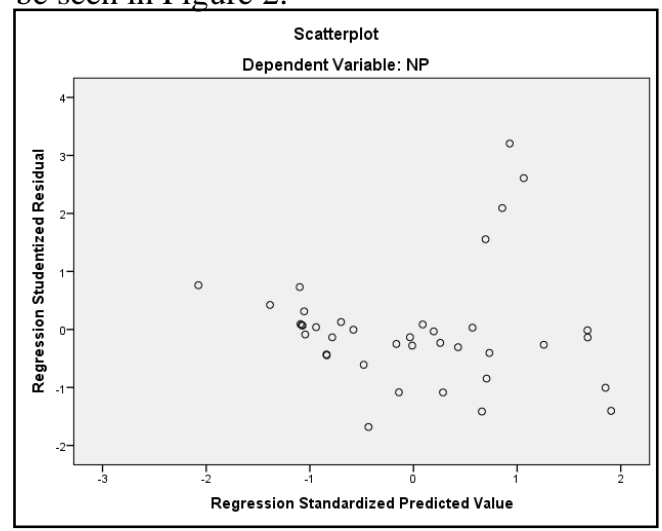

Figure 2 Heteroscedasticity Test

Based on Figure 2, it can be concluded that the model does not occur heteroscedasticity. This can be seen from the random distribution of points that do not form a certain pattern

\section{Autocorrelation Test}

Based on Table 6, it is known that the DW value of each dependent variable is the firm value of 2,525. The two

\begin{tabular}{lcccc}
\hline & $\begin{array}{c}\text { Original } \\
\text { Sample } \\
(\boldsymbol{O})\end{array}$ & $\begin{array}{c}\text { Sample } \\
\text { Mean } \\
(\boldsymbol{M})\end{array}$ & $\begin{array}{c}\text { T Statistics } \\
(\mid \text { O/STERR } \mid)\end{array}$ & $\begin{array}{c}\boldsymbol{P} \\
\text { Values }\end{array}$ \\
\hline $\begin{array}{l}\text { CSR }-> \\
\text { NP }\end{array}$ & $-0,1049$ & $-0,0882$ & 0,8302 & 0,4068 \\
\hline $\begin{array}{l}\text { GCG -> } \\
\text { NP }\end{array}$ & $-0,0868$ & $-0,0910$ & 0,6805 & 0,4965 \\
\hline
\end{tabular}

DW values are located between the upper bound (dl) and (4-dl), which is between 1.594 for 38 observation data and 2 independent variables and 2.627. Based on these criteria, it is concluded that there is no autocorrelation.

Table 6 Durbin Watson Nilai Value

\begin{tabular}{c}
\multicolumn{2}{c}{ Model Summary ${ }^{\mathrm{b}}$} \\
\hline Durbin-Watson \\
\hline
\end{tabular}

b. Dependent Variable: NP

Sumber: Output SPSS

\section{Hypothesis test}

Based on the tests that have been carried out using the SmartPLSTM Version 3.2.1 program, the effect of each variable in detail can be seen in Table 7.

Tabel 7 Path Coefficients

\begin{tabular}{lcccc}
\hline & $\begin{array}{c}\text { Original } \\
\text { Sample } \\
(\boldsymbol{O})\end{array}$ & $\begin{array}{c}\text { Sample } \\
\text { Mean } \\
(\boldsymbol{M})\end{array}$ & $\begin{array}{c}\text { T Statistics } \\
(\mid \text { O/STERR } \mid)\end{array}$ & $\begin{array}{c}\boldsymbol{P} \\
\text { Values }\end{array}$ \\
\hline $\begin{array}{l}\text { CSR -> } \\
\text { NP }\end{array}$ & $-0,1049$ & $-0,0882$ & 0,8302 & 0,4068 \\
\hline GCG -> & $-0,0868$ & $-0,0910$ & 0,6805 & 0,4965 \\
NP & $-0,0865$ \\
\hline
\end{tabular}

Sumber : Output SmartPLS ${ }^{\mathrm{TM}}$
Based on Table 7, it can be concluded that the hypothesis testing between variables is as follows:

The Influence of GCG and CSR on Company Value

Table 7 shows the equations for measuring firm value obtained based on the results of statistical calculations are:

$$
\mathrm{Y}=-0,0910 \mathrm{X} 1-0,0882 \mathrm{X} 2+\mathrm{e} 1
$$

The GCG variable (X1) has a path coefficient of 0.0910 with a $\mathrm{P}$ Value $>0.05$, meaning that no matter how much increase in the level of disclosure of GCG information, it will not affect the value of companies in Indonesia.The CSR variable (X2) has a path coefficient of -0.882 with $\mathrm{P}$ Value $>0.05$, meaning that no matter how much the level of increase in the presentation of CSR information will affect the value of companies in Indonesia.

The test results indicate that testing the fourth hypothesis, namely GCG and CSR together, has an acceptable effect on firm value (Ha1 is rejected; H01 is accepted). The criteria for determination are based on the GCG and CSR path coefficient values $0, \mathrm{i}=1,2$, namely -0.0910 and -0.0882 .

\section{The Effect of GCG on Company Value}

Based on the GCG hypothesis test on firm value seen in Table 7, the relationship between the GCG variable and firm value shows a path coefficient value of -0.0910 with a t-statistical value of 0.6805 . This value is smaller than t table (2.024) with a $\mathrm{P}$ Value > 0.05 . This result means that GCG is not significant to firm value so Ha2 is rejected; H02 is accepted. Thus, it can be said that GCG has no effect on firm value.

\section{The Effect of CSR on Company Value}

The test of the CSR variable on firm value can be concluded by looking at Table 7 which shows that the path coefficient value is -0.0882 with a t-statistical value of 0.8302 . This value is smaller than t table (2.024) with a $\mathrm{P}$ Value $>0.05$. This result means that CSR is not significant to firm value so $\mathrm{Ha} 3$ is rejected; $\mathrm{H} 03$ is accepted. Thus, it can be said that CSR has no effect on firm value.

\section{Coefficient of Determination Test (Adjusted $\mathbf{R}^{\mathbf{2}}$ )}

Testing of the inner model or structural model is carried out to see the relationship between constructs, significance values and $\mathrm{R}$ square of the research model. Table 8 shows the value of $\mathrm{R}$ square for the influence between variables in this study.

Table 8 Values R Square Model Summary

\begin{tabular}{ccccr}
\hline Model & $\mathbf{R}$ & $\begin{array}{c}\mathbf{R} \\
\text { Square }\end{array}$ & $\begin{array}{c}\text { Adjusted } R \\
\text { Square }\end{array}$ & $\begin{array}{c}\text { Std. Error of } \\
\text { the Estimate }\end{array}$ \\
\hline 1 &, $3709^{\mathrm{a}}$ &, 4310 &,- 075 &, 0611661 \\
\hline
\end{tabular}

a. Predictors: (Constant), GCG, CSR

b. Dependent Variable: The value of the company

Source: Output SPSS 
The Influence of Good Corporate Governance and Corporate Social Responsibility on the Value of Banking Companies Listed on the Indonesia Stock Exchange

Anhar Firdaus, Fazli Syam BZ, Yossi Diantimala, Syawal Harianto
Based on Table 8 , it can be seen that the R Square value for the firm value variable is 0.4310 or $43.10 \%$. Thus it can be said that $43.10 \%$ of the variation in firm value can be explained by the independent variables in this study, namely GCG and CSR as well as financial performance as a mediator, while the remaining $56.90 \%$ (1-R2) is explained by other variables not mentioned in the model. this research.

\section{The Effect of GCG on Company Value}

The value of $\mathrm{P}$ Value $>0.05$ for the GCG variable (X1) on the value of the company in Table 7 shows that GCG has no effect on the value of the company in companies in Indonesia for the period 2011-2015. The positive perception of the CGPI index rating released by IICG makes investors react positively to the company's shares so that the company's share price will increase which in turn will increase the value of the company. It's just that the implementation of good GCG is not enough to make investors make investment decisions, but there are other variables that can influence a very large share in determining investment decisions made by investors such as financial performance. The results of this study are consistent with the results of previous studies conducted by Pertiwi and Pratama (2012), but differ from the results of research conducted by Cheung et al (2014) and Wardoyo and Veronica (2013).

\section{The Effect of CSR on Company Value}

Table 7 shows that CSR (X2) has a P Value > 0.05 . This shows that CSR has no effect on firm value. Guidelines for CSR disclosure and the possibility of transitioning methods for CSR disclosure guidelines where reporting organizations use the G3 or G3.1 Guidelines can be one factor in the low CSR disclosure by some companies compared to companies that have directly implemented the G4 Guidelines. The results of this study are in line with research conducted by Wardhani (2013) and Wardoyo and Veronica (2013), but different from the results of research conducted by Latupono and Andayani (2015)..

\section{CONCLUSIONS}

Berdasarkan hasil penelitian dan pembahasan pada bab Previously, it can be concluded that testing the first hypothesis shows that GCG and CSR together have no effect on firm value. The results of testing the second hypothesis show that GCG has no effect on firm value. The results of testing the third hypothesis indicate that CSR has no effect on firm value.

Further research should add that there are several limitations in conducting research on banking companies that have CGPI values in Indonesia and are listed on the Indonesia Stock Exchange for the period 2011-2015, so the results cannot be generalized to banking in Indonesia in general. two) guidelines, namely GRI 3.1 and GRI G4. The observation period was relatively short for 5 years, from 2011 to 2015 , and there were still very limited reference sources on the variables in this study. Further researchers are expected to be able to use the types of financial performance indicators so that the research results obtained are more comprehensive. Using the latest CSR disclosure indicators and can add other variables that affect the level of financial performance and firm value. 
The Influence of Good Corporate Governance and Corporate Social

Responsibility on the Value of Banking Companies Listed on the

Indonesia Stock Exchange

Anhar Firdaus, Fazli Syam BZ, Yossi Diantimala, Syawal Harianto

\section{REFERENCE}

Belkaoui, A. R. (2000). Teori Akuntansi. Buku 1. Jakarta: Salemba Empat.

CLSA. (2003). CG Watch: Corporate Governance in Asia. Hongkong: Asian Corporate Governance Association.

Dewi, L. N. dan Ketut A.S. (2015). Pengaruh Keputusan Investasi dan Good Corporate Governance pada Kinerja Keuangan serta Implikasinya pada Nilai Perusahaan. E-Jurnal Akuntansi Universitas Udayana. 12. 3: 786-802.

Ghazali and Chariri. (2007). Teori Akuntansi. Semarang: Badan Penerbit Undip.

Gujarati, D. N.. (2003). Basic Econometrics: Fourth Edition. New York: Mc Graw Hill.

International Standart ISO 26000:2010. First Edition. Guidance on Social Responsibility.

Jensen, M. C. dan Meckling, W. H. (1976). Theory Of The Firm: Manajerial Behavior, Agency Cost And Ownership Structure, Journal of Financial Economics, 3, pp: 305-360.

Maassen, G. F. (2000). An International Comparison of Corporate Governance Models. Amsterdam-The Netherlands: Spencer Stuart.

Martono dan Agus H. (2006). Manajemen Keuangan. Edisi Kedua. Yogyakarta: Ekonisia.

Otoritas Jasa Keuangan. (2016). Peraturan Otoritas Jasa Keuangan No. 55/POJK.03/2016 tentang Penerapan Tata Kelola bagi Bank Umum.

Pertiwi, T.K. dan Ferry M. I. P. (2012). Pengaruh Kinerja Keuangan, Good Corporate Governance terhadap Nilai Perusahaan Food and Beverage. Jurnal Manajemen dan Kewirausahaan. 14. 2: 118-127.

Republik Indonesia. Undang-Undang No. 40 Tahun 2007 tentang Tanggung Jawab Sosial dan Lingkungan.

Sekaran, U. (2006). Research Methods for Business: Metodologi Penelitian untuk Bisnis. Edisi 4. Terjemahan Kwan Men Yon. Jakarta: Salemba Empat.

Smithers, A. dan Stephen W. (2007). Valluing Wall Street: Protecting Wealth in Turbulent Markets. New York: Mc Graw Hill.

Sugiyono, A. (2009). Manajemen Keuangan untuk Praktisi Keuangan. Jakarta: Grasindo.

Suprayitno dkk. (2009). Good Corporate Governance dalam Perspektif Manajemn Stratejik. Jakarta: The Indonesian Institute for Corporate Governance.

Wardhani, R. S. (2013). Pengaruh CSR Disclousure terhadap Nilai Perusahaan dengan Kinerja Keuangan sebagai variabel intervening (Studi Kasus Perusahaan Manufaktur yang Terdaftar di BEI). Jurnal Ekonomi Akuntansi dan Manajemen. 12. 1: 54-86.

World Business Council for Sustainable Development. (1998). Corporate Social Responsibility: Meeting Changing Expectations. Switzerland: The World Business Council for Sustainable Development.

Zhung, J. Et al. (2000). Corporate Governance and Finance in East Asia. Vol. 1. Manila: Asian Development Bank 